\begin{tabular}{|c|c|c|c|c|c|c|c|c|}
\hline & \multicolumn{5}{|c|}{ Year of medical course } & \multicolumn{3}{|c|}{ Smoking behaviour } \\
\hline & $\begin{array}{c}1 \\
\text { (87 men, } \\
67 \text { women) }\end{array}$ & $\begin{array}{c}2 \\
\text { (40 men, } \\
59 \text { women) }\end{array}$ & $\begin{array}{c}3 \\
\text { (59 men, } \\
84 \text { women) }\end{array}$ & $\begin{array}{c}4 \\
\text { (57 men, } \\
76 \text { women) }\end{array}$ & $\begin{array}{c}5 \\
\text { (49 men, } \\
45 \text { women) }\end{array}$ & $\begin{array}{l}\text { Non-smoker } \\
\text { (197 men, } \\
245 \text { women) }\end{array}$ & $\begin{array}{l}\text { Ex-smoker } \\
\text { (28 men, } \\
33 \text { women) }\end{array}$ & $\begin{array}{c}\text { Current smoker } \\
\text { (67 men, } \\
51 \text { women) }\end{array}$ \\
\hline \multicolumn{9}{|c|}{ Medical and nursing students have knowledge to advise patients to stop smoking } \\
\hline Male & $52(60)$ & $32(80)$ & $42(72)$ & $47(83)$ & $38(78)$ & $142(72)$ & $19(68)$ & $50(76)$ \\
\hline Female & $38(58)$ & $34(61)$ & $55(66)$ & $63(84)$ & $37(82)$ & $173(71)$ & $24(73)$ & $30(60)$ \\
\hline \multicolumn{9}{|c|}{ Medical and nursing students have authority to advise patients to stop smoking } \\
\hline Male & $28(32)$ & $16(40)$ & $22(38)$ & $17(30)$ & $31(63)$ & $85(43)$ & $11(39)$ & $18(27)$ \\
\hline Female & $18(27)$ & $20(36)$ & $29(35)$ & $33(43)$ & $16(36)$ & $90(37)$ & $12(36)$ & $14(28)^{-}$ \\
\hline \multicolumn{9}{|c|}{ One Individual has right to advise another to stop smoking } \\
\hline Male & $64(74)$ & $30(75)$ & $39(67)$ & $40(70)$ & $41(84)$ & $155(79)$ & $18(64)$ & $41(62)$ \\
\hline Female & $41(61)$ & $33(59)$ & $62(74)$ & $55(72)$ & $32(71)$ & $178(73)$ & $18(55)$ & $27(54)$ \\
\hline
\end{tabular}

agreed that doctors and nurses should not smoke $(\mathrm{P}=0.012$ for women and $\mathrm{P}<0.001$ for men). As table 1 shows, however, while most students in all years agreed that they had the knowledge to advise patients to stop smoking, they were far less likely to agree that they had the authority to do so. Surprisingly, few students disagreed with the statement that one person has the right to advise another person to stop smoking.

Our findings show that the prevalence of smoking among medical students may be rising. Students seem to perceive their student status as impeding them from advising patients and others about stopping smoking. The problem based curriculum that is now in place will help students to develop the skills and confidence needed to overcome these reservations. Doctors' advice to patients with regard to stopping smoking has been shown to be effective, ${ }^{23}$ so it is important that these issues should be covered in medical courses and that newly qualified doctors should emerge with knowledge and confidence to carry out this important task.

We thank the Cancer Research Campaign and Japanese Ministry of Education for financial support and Dr Ann Cockcroft, of the Royal Free Hospital, London, for help with the questionnaire.

YOSHIKATSU MOCHIZUK Visiting research fellow

Asahikawa Medical College,

Department of Public Health

5-Go, Nishikagura, 4-Sen,

Asahikawa,

Hokkaido 078,

Japan

DAVID WHILE

Statistician

ANNE CHARLTON

Directo

CRC Education and Child Studies Research Group

School of Epidemiology and Health Sciences,

School of Epidemiology and

University of Manchester,

1 Knopf Elkind A. Changes in the smoking behaviour, knowledge and opinions of medical students 1972-1981. Soc Sci Med 1982;16:2137-43.

2 Russell MAH, Wilson C, Taylor C, Baker CD. Effect of general practitioners' advice against smoking. $B M$ F 1979;ii:231-5.

3 Campbell IA, Lyons E, Prescott RJ. Stopping smoking: do nicotine chewing-gum and postal encouragement add to doctors' advice? Practitioner 1987;231:114-7.

\section{Making decisions with children}

Asking children to participate in decisions about their care undermines parents' position

EDrToR,-It is clear from his editorial advocating that children should participate in decisions about their care that George Rylance has not the remotest idea of what is involved in the day to day care of children in a surgical context, where issues of consent most commonly arise. ${ }^{1}$ The extraordinary proposals outlined in his editorial and in the Institute of Public Policy Research's document from which he quotes - that consent independent of that of the parents should be obtained from the child for virtually every procedure carried out in hospital, from being weighed and measured onwards-would unleash a cocktail of bureaucracy, litigation, and time wasting in attempts to give children total authority in every procedure proposed for them in a hospital. This pernicious philosophy comes from the same stable as that which presumes all parents guilty of injury or abuse of their children until proved otherwise. Like that doctrine-of whose disastrous results we are painfully aware-it weakens the position of parents by denying that they are the people closest to their child and in the vast majority of cases have the child's best interest at heart (more so even than the paediatricians do) and are therefore in the best position to translate and explain a doctor's properly given advice.

P J MAHAFFEY

Lister Hospital, Consultant plastic surgeon

Stevenage SG1 $4 A B$

1 Rylance G. Making decisions with children. $B M F$ 1996;312:794. (30 March.)

\section{Author's reply}

EDrToR,-I expected that the code of practice suggested by the Institute of Public Policy Research might be seen by some doctors to be extreme, impracticable, and potentially time wasting. It seems, however, to be a logical extension of the practice of talking with child patients, giving explanations and advice, and involving them in decision making. It is apparent that not all doctors believe in this approach. Adult patients usually have the power to argue their rights and make clear their needs and demands. Children who are recognised to be competent to share in and make decisions have similar rights to adults, but the paternalistic attitude of some doctors and the imbalance of power in doctor-patient relationships make it necessary for others to speak up for children and their rights.

The code of practice represents a framework within which doctors, children, and parents can work together in making health care decisions. It in no way seeks to separate a child's decision making process from that of the parents but recognises the need for children to be treated as individuals capable of considering options and making decisions about their care.

I am aware that the suggested approach may produce difficulties, and debate about it is essential. Nevertheless, I think that P J Mahaffey's concerns are exaggerated. My work, like that of most paediatricians, entails much decision making with children and parents each day, albeit not usually concerning consent to surgery. I have practised over a number of years in a manner broadly similar to that suggested by the Institute of Public Policy Research and have not recognised any particular difficulties. Many adult and -child patients report that there has been inadequate information, explanation, and discussion in their consultations with doctors, and this is clearly unsatisfactory. I hope that children's fundamental needs and rights will not be further denied by spurious concerns about increased bureaucracy, time, and litigation.

GEORGE RYLANCE Consultant paediatrician

Birmingham Children's Hospital NHS Trust,

Birmingham B16 8ET

\section{Volunteering children for bone marrow donation}

Studies show large discrepancies between views of surrogate decision makers and patients

EDITOR, - The articles on the ethics of volunteering children for bone marrow donation raise several issues about proxy or surrogate decision making. ${ }^{1}$ The central issue concerns the identification of the donor's and family's best interests, when the decision maker must determine the highest benefit from available options.

Although many philosophical questions are involved, there are also empirical questions to be asked. The validity of surrogate decision making rests on the assumption that the decision maker can gauge the individual's needs, views, or interests with some accuracy, or at least with more accuracy than others. Julian Savulescu argues that "parents know their children better than social workers, who are poorly placed to know what kind of family they are, how close they are." Some studies have compared the views of health care professionals and parents with those of patients and children. Do parents and professionals get it right?

Many studies have shown that there can be a large discrepancy between the views and experiences of potential surrogate decision makers and adult patients. ${ }^{2}$ Generally speaking, professionals underestimate the levels of pain or distress, and the discrepancy can be large. Other patients are sometimes more accurate at identifying difficulties than professionals. While there are fewer studies comparing parents' and children's views, a similar pattern emerges. For example, there can be very low agreement between parents' and child patients' views of psychiatric treatment, with parents underestimating the child's feelings of distress, anxiety, and negative reactions. ${ }^{4}$ In a study on perceptions of pain, nurses', parents', and children's own reports during venepuncture were compared. The correlation between parents' and their child's ratings of pain was modest, and, contrary to Savulescu's contention, nurses were better at estimating children's discomfort than were parents. 
These studies show the dangers of making ethical pronouncements in an empirical vacuum. There is a pressing need for more research on how proxy decision makers arrive at their recommendations for treatment. With regard to bone marrow donation, parents have several obligations. Not only do they have to keep the best interests of the two children in mind but they also have to come to a mutually acceptable solution that will at least maintain their partnership. Just as there is now much emphasis on evidence based medical practice, so too ought there to be more interest in evidence based ethical practice.

GERRY KENT

Senior lecturer in medical psychology

Sheffield Centre for Health and Related Research,

University of Sheffield,

Sheffield S1 4DA

1 Delany L, Month S, Savulescu J, Browett P, Palmer S. Altruism by proxy: volunteering children for bone marrow donation. BMf 1996;312:240-3. (27 January.)

2 Herbert C, Salmon P. The inaccuracy of nurses' perception of elderly patients' well-being. Psychology and Health 1994;9:485-92.

3 Bradley C, Brewin C, Duncan S. Perceptions of labour: discrepancies between midwives' and patients' ratings. $\mathrm{Br}$ Obstet Gynaecol 1983;90:1176-9.

4 Kazdin A, French N, Sherick $R$ Acceptability of alternative treatments for children; evaluations by inpatient children, parents and staff. Consulting and Clinical Psychology parents and

5 Manne S, Jacobsen P, Redd W. Assessment of acute pediatric pain: do child self-report, parent ratings ant nurse rating measure the same phenomenon? Pain 1992;48:45-52.

Children's views should have been

represented in discussion

EDITOR,-I find it odd that in the discussion of bone marrow transplantation the opinion of children was not sought. ${ }^{1}$ I therefore turned to my local panel of experts, my children aged 5 to 11 . I asked if they would be willing to provide a bone marrow transplant for one of their siblings. I explained the procedure, the discomforts, and the small possibility of death resulting from the anaesthetic. They initially found some of the information confusing, but from their questions it was obvious that the three oldest (aged 7 to 11) understood and agreed to transplantation. My 5 year old was problematic, refusing to donate to his sisters because they would not let him into their room. Try as I might, he could not grasp the issues concerned.

I also explained that some people thought that children should not be allowed to donate bone marrow because donation does not do the donor child any good. My 9 year old summed up the views of the group succinctly: "That's stupid. Why wouldn't you want to save someone's life if you could?" She would have to ask a lawyer for an answer: I could not think of one.

W E OSMUN Assistant professor

Department of Family Medicine,

University of Western Ontario

London, Ontario,

Canada

1 Delany L, Month S, Savulescu J, Browett P, Palmer S. Altruism by proxy: volunteering children for bone marrow donation.

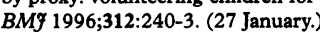

\section{Children may be able to make their own decisions}

EDrTOR,-The discussion on volunteering children for bone marrow donation makes many important points about proxy decisions affecting children. ${ }^{1}$ None of the authors, however, considers the possibility of children making decisions themselves, or even of adults taking account of children's views. Linda Delany refers to the case of Gillick but not to the main conclusion of the case, which was that children can give legally valid consent when "they have sufficient understanding and intelligence to understand fully what is proposed."2
Assumptions about the age at which children are able to make wise decisions tend to be based on ill founded historical prejudices about children's supposed inabilities and on psychological research about their responses to hypothetical questions. Children who have experience of severe illness and treatment tend to give far more informed responses than inexperienced ones. Young siblings of children in need of bone marrow transplants are likely to know a great deal about the implications of offering or withholding this treatment and to have clear views of their own.

We have reviewed the legal obligations of adults to listen to young children and to involve them in decisions that affect them, with the benefits and risks of doing so. ${ }^{3}$ While supporting high standards of clinical practice and professional ethics we have proposed ways of putting into policy and practice the idea that children can give legally valid consent (as was the judgment in the Gillick case).

Social Science Research Unit,

PRISCILLA ALDERSON

Institute of Education,

University of London,

University of London,
London WC1H ONS

JONATHAN MONTGOMERY Senior lecture

Faculty of Law

University of Southampton

Southampton $\mathrm{SO} 5 \mathrm{NH}$

1 Delany L, Month S, Savulascu J, Browett P, Palmer S. Altruism by proxy: volunteering children for bone marrow donation. $B M \Im$ 1996;312:240-43. (27 January.)

2 Gillick $v$ West Norfolk and Wisbech Area Health Authority [1985] 3 All ER 423.

3 Alderson P, Montgomery J. Health care choices: making decisions with children. London: Institute for Public Policy Research, 1996.

\section{Moving medical malpractice insurance to Medical Insurance Agency may be expensive}

EDITOR,-For 15 years I was insured for medical malpractice through a traditional defence union. Then, in 1991, I moved my insurance to the Medical Insurance Agency: the premium was related to the doctor's perceived risk and was half what my payment to the defence union had been Subsequently I asked for legal advice about a letter to a patient whom I had put off my list. The agency's London based solicitor needed my confirmation that the rules covering this in the red book were the same in Scotland as in England and Wales. This did not inspire my confidence in the company's ability, and in 1994 I moved my insurance back to the traditional defence union Too late I discovered that the policy that the agency had offered me did not offer retrospective cover unless further unspecified amounts were paid for an undefined number of years. The agency is the only company underwriting this type of policy, and none of the defence unions is prepared to assume my risk. They offer doctors retrospective cover for the years that they were a member. Curiously, the agency does not emphasise this difference prominently in any of its advertising.

The BMA had not heard of this problem but suggested that I wrote to the chairman of the Medical Insurance Agency. After an exchange of correspondence the company said that the item in its brochure on "run off" cover was adequate. I complained to the insurance ombudsman, who was unable to investigate my complaint since the problem was not within his remit.

I am extremely angry at being forced to remain insured with the Medical Insurance Agency or to pay run off cover for the rest of my professional life and my retirement. I am left counting the cost of not seeking clarification of what exactly run off cover would mean in financial terms. I urge all doctors who may consider changing their indemnity insurance to the Medical Insurance Agency to seek written explanation of run off cover, otherwise it may cost them dear.

FIONA NICOL General practitioner

Stockbridge Health Centre,

1 India Place,

Edinburgh EH3 6EH

\section{Warfarin should be available as $0.5 \mathrm{mg}$ tablet}

EDITOR,-We recently reviewed the pattern of anticoagulant treatment at our hospital before computerisation to absorb the increased workload. We have seen a particular increase in the use of anticoagulants in elderly people. As expected, there was an inverse correlation between the dose of warfarin and age. Most of the elderly people were not treated with a single daily dose: over three fifths required either an alternating daily dose or a more complex regimen over three to seven days to achieve stable therapeutic anticoagulation. These types of regimen are confusing for elderly patients and are difficult to administer and to communicate to patients.

At present, warfarin is available in $1 \mathrm{mg}, 3 \mathrm{mg}$, and $5 \mathrm{mg}$ tablets; these are difficult to divide. We suggest that a $0.5 \mathrm{mg}$ tablet should be introduced, which should be of a nationally agreed colour. Possibly it should be scored to allow the introduction of $0.25 \mathrm{mg}$ doses.

G ROUSE Clinical assistant

J POPE

Pharmacist R G DALTON

Cheltenham General Hospital,

Consultant haematologis

Cheltenham GL53 7AN

Advice to author

We receive more letters than we can publish: we can currently accept only about one third. We prefer short letters that relate to articles published within the past four weeks. Letters received after this deadline stand less chance of acceptance. We also publish some "out of the blue" letters, which usually relate to matters of public policy.

When deciding which letters to publish we favour originality, assertions supported by data or by citation, and a clear prose style. Wit, passion, and personal experience also have their place.

Letters should have fewer than 400 words (please give a word count) and no more than five references (including one to the $B M F$ article to which they relate); references should be in the Vancouver style. We welcome pictures.

Letters should be typed and signed by each author, and each author's current appointment and address should be stated. We encourage you to declare any conflict of interest.

Please enclose a stamped addressed envelope if you would like to know whether your letter has been accepted or rejected.

Letters will be edited and may be shortened. 